Article

\title{
Depuration Performance of Aerated Tanks Simulating Lagoons to Treat Olive Oil Mill Wastewater under Different Airflow Rates, and Concentrations of Polyphenols and Nitrogen
}

\author{
Serafina Andiloro (D), Giuseppe Bombino, Pietro Denisi (D), Adele Folino (D), Demetrio Antonio Zema *(D) \\ and Santo Marcello Zimbone
}

Citation: Andiloro, S.; Bombino, G.; Denisi, P.; Folino, A.; Zema, D.A.; Zimbone, S.M. Depuration Performance of Aerated Tanks Simulating Lagoons to Treat Olive Oil Mill Wastewater under Different Airflow Rates, and Concentrations of Polyphenols and Nitrogen.

Environments 2021, 8, 70.

https://doi.org/

10.3390 /environments 8080070

Academic Editor: Alfredo Cassano

Received: 26 June 2021

Accepted: 21 July 2021

Published: 23 July 2021

Publisher's Note: MDPI stays neutral with regard to jurisdictional claims in published maps and institutional affiliations.

Copyright: (C) 2021 by the authors Licensee MDPI, Basel, Switzerland. This article is an open access article distributed under the terms and conditions of the Creative Commons Attribution (CC BY) license (https:// creativecommons.org/licenses/by/ $4.0 /)$
Department Agraria, Mediterranea University of Reggio Calabria, Località Feo di Vito, I-89122 Reggio Calabria, Italy; serafina.andiloro@unirc.it (S.A.); giuseppe.bombino@unirc.it (G.B.); pietro.denisi@unirc.it (P.D.); adelefolino@alice.it (A.F.); smzimbone@unirc.it (S.M.Z.)

* Correspondence: dzema@unirc.it

Abstract: The uncontrolled disposal of olive oil mill wastewater (OMW) is hazardous for the health of water and soil, since this wastewater shows low $\mathrm{pH}$ and high contents of organic matter and polyphenols (PP). Lagooning is one of the most common treatment systems for agro-industrial wastewater (such as OMW), due to its low cost and easy management. Aeration allows reducing the low depuration time, which is a constraint for this system. Despite this potential feasibility, literature about OMW lagooning is not abundant. Moreover, the effects of the aeration rates, concentration of polyphenols and nitrogen shortage on depuration performance of lagoons treating OMW have not been properly explored. This study analyzes the removal rates of COD and $\mathrm{PP}$, and variations of $\mathrm{pH}$ in OMW treated in aerated tanks at the laboratory scale simulating lagooning systems. Compared to the non-aerated tanks, aeration of OMW increased the removal rates from $61 \%$ to $90 \%$ (for COD) and from $52 \%$ to $64 \%$ (for PP). Permanent aeration was more advisable compared to intermittent flow rates. Increasing concentrations of PP noticeably reduced the COD removal rates, which were halved at a 4-fold PP concentration. In contrast, the PP removal rate was constant at every concentration experimented. Compared to the COD:N value suggested by literature for aerobic processes (100:5), a shortage in nitrogen availability reduced both COD (by about 20-25\%) and PP removal rates (by 25\%), the latter only when COD:N was higher 400:5. The $\mathrm{pH}$ was less influenced by the variations in aeration rates, PP concentration and COD:N ratio compared to COD and PP removal. This investigation provides indications about the most suitable operation parameters (airflow rates, inhibiting PP concentration, and optimal COD:N) in aerated lagooning of OMW towards environmentally sound treatments of highly polluting wastewater.

Keywords: aerated tanks; $\mathrm{COD} ; \mathrm{pH}$; airflow rate; $\mathrm{COD}: \mathrm{N}$ ratio; environmental pollution; depuration performance

\section{Introduction}

Management of the residues produced by the olive oil industry is a challenging task, due to their large volume and specific physico-chemical properties [1,2]. The so-called "olive pomace", which is a wet and solid biomass, and the "olive oil mill wastewater" (hereinafter OMW), which is a liquid effluent, is about $30 \%$ and $50 \%$ of the total amount of olive processed, while the olive oil is $20 \%$ [3,4]. With specific regard to OMW, this effluent shows high concentrations of organic matter (OM), suspended solids and inhibiting compounds, such as polyphenols (hydroxytyrosol, tyrosol, catechol, methylcatechol, caffeic acid) [5-7]. These characteristics make the uncontrolled disposal of OMW hazardous for the health of water and soil, since pollution of surface bodies and ground water, as well as degradation of soil properties, is possible [8-10]. The acidic $\mathrm{pH}$ and the high contents of organic matter and polyphenols are the OMW properties that potentially have the most 
hazardous effects on water and soils [11]. The 10 million $\mathrm{m}^{3}$ of OMW that are yearly produced worldwide have an environmental impact equalling the wastewater generated by 20 million inhabitants [12,13].

To avoid or at least reduce these heavy environmental risks, suitable management is needed. Several treatment systems have been proposed for OMW for a long time. Currently, the methods applied for OMW treatment are physico-chemical or biological. Physicochemical methods include simple evaporation, reverse osmosis, ultrafiltration, coagulation, oxidation, thermal drying and advanced oxidation processes), while the biological systems consist of aerobic treatment, composting, vermicomposting together with other agroindustrial residues, and anaerobic digestion $[3,14,15]$. The latter is a promising technology for the valorization of olive oil residues, since it produces renewable energy (biomethane). However, anaerobic digestion is not a completely mature treatment process, because many issues need to be overcome in the case of application to OMW [16-18].

Land spreading on soil for crop irrigation is the most traditional system [19], but this requires sufficient land area and soils of suitable characteristics, since OMW application may be toxic for plants and bacteria living in soils $[19,20]$. The intensive depuration plants (activated sludge or percolating filters) are expensive and suffer from process instability (due to the OMW characteristics). Valorization of OMW in biorefineries (for recovering value-added products) or in energy production plants (using anaerobic digestion) is still not a mature alternative, since some technical and economic problems need yet to be overcome (e.g., low product yields of biorefinery processes and toxicity of polyphenols for microorganisms of anaerobic processes) $[17,21]$. Furthermore, the other physico-chemical and biological OMW treatments have been found to be complex and expensive, particularly for the small oil mills $[15,17]$. In contrast, natural treatments have been proposed as suitable alternatives to the management systems mentioned above. Natural systems have been experimented and applied particularly for urban wastewater (e.g., [22,23]), but are promising also for agro-industrial wastewater, such as OMW [24]. These systems include constructed wetlands and lagoons. Constructed wetlands are not the optimal system for OMW treatment, since polyphenols and high $\mathrm{pH}$ are phytotoxic. Lagoons have instead been employed to treat high-strength wastewaters [25] from municipal, agricultural, and industrial sources, including agro-industries [26]. Generally speaking, lagooning is a low-cost wastewater treatment system, thanks to cheap construction, operation, and maintenance as well as the absence or low requirement of mechanical equipment $[25,27]$. This system effectively removes several contaminants, such as organic matter, nutrients, heavy metals, and pathogens [28], and makes it possible to treat wastewater throughout the whole year, although effluents are produced in a much shorter period for agro-industrial wastewater [29]. This gives lagooning systems the capacity of buffering fluctuations in wastewater flow and load [26].

A lagoon is a large reservoir (with depth from a few to several metres), where wastewater is stored and treated through natural processes, such as sedimentation and biodegradation; the latter is due to the activity of microorganisms (mainly bacteria) $[25,30,31]$. The storage period into lagoons can be considered as a natural biological treatment method [13]. The main disadvantage of lagooning is the large land requirement, which has confined the application of lagoons to rural areas [28]. However, this is not a constraint for olive oil mills, which are often small enterprises or family businesses that are located in olive groves [10,32]. At present, in the Mediterranean countries, OMW treatment in lagoons is the most used management option, often in combination with land spreading $[3,13,33]$.

Although the literature about lagooning of urban wastewater is ample [34], less research is available for agricultural effluents [35]. An overview of the OMW treatments, mainly focused on organic matter degradation by chemical and biological processes, is reported in Mantzavinos and Kalogerakis [36]. In Tunisia, S'habou et al. [33] evaluated the lagoon performance to treat OMW, and detected wastewater infiltration in the subsoil, which altered the $\mathrm{pH}$, electrical conductivity, and organic content of soil. Jail et al. [37] experimented with the co-treatment of OMW and urban wastewaters in lagoons, showing 
the high influence of the applied wastewater load on the removal of the organic and phenolic compounds. In another investigation, the same authors [38] treated OMW combining an intensive treatment (Jet-Loop Reactor) and lagooning, achieving a reduction in OM and phenols by about $70 \%$ for both. In the work of Benitez et al. [34], the aerobic treatment carried out by lagooning achieved the significant removal of COD and phenols from OMW, but the system was less effective in eliminating aromatic substances. Hybrid treatment systems consisting of lagoons and constructed wetlands were tested by Gikas et al. [27], who stated that the final effluent concentrations remained high for disposal in water bodies and suggested combining the systems in series. However, according to the latter authors, there are limited studies on OMW treatment using lagooning systems, since special emphasis was given to constructed wetlands [27].

Often, the wastewater is aerated to fasten these natural processes (usually requiring weeks or months) and mixing the stored effluents to equalize their physico-chemical characteristics. In spite of the satisfactory depuration efficiency of the aerated lagoons, the use of these treatments is limited by the aeration cost [7]. The airflow rates and aeration times are not standardized in literature, and the setting-up of these operation parameters is not easy $[35,39]$, requiring targeted aeration tests.

Moreover, the effects of the specific characteristics of OMW on the depuration efficiency have not been completely understood. More specifically, it is well known that polyphenols (whose concentration ranges between 0.5 and $24 \mathrm{~g} / \mathrm{L}$ in OMW $[40,41]$ ) are toxic for both aerobic and anaerobic micro-organisms, and this toxicity slows down or even blocks the depuration processes [42,43]. Additionally, the shortage of nutrients (particularly nitrogen), compared to the carbon content of OMW, which is typical of the effluents of agro-industries [44], may enhance the growth of filamentous bacteria in intensive depuration processes. These bacteria [45] can take advantage of other micro-organisms, because of their higher surface/volume ratio, and their excessive growth reduces the depuration efficiency [39]. However, the effects of high concentrations of polyphenols and nitrogen shortage in OMW treated in aerated lagoons have not been yet explored in depth.

To fill these gaps, this study analyzes the depuration performance (chemical oxygen demand, $\mathrm{pH}$ and polyphenols, hereinafter indicated as "COD" and "PP", respectively) in OMW treated in aerated tanks at the laboratory scale, which simulates the biochemical processes acting in lagoons. The specific objectives of this investigation are the evaluation of the removal rates of COD and $\mathrm{PP}$, and of the variation of $\mathrm{pH}$ in three series of depuration tests: (i) under two air flow rates and aeration times, compared to a non-aerated tank; (ii) under three PP concentrations; (iii) under three COD vs. N ratio.

\section{Materials and Methods}

\subsection{Description of the Experimental Pilot Plant}

OMW was produced by a 3-phase olive oil mill and immediately stored in small tanks simulating a small-scale lagoon. Each tank, having a cylindrical volume equal to $0.1 \mathrm{~m}^{3}$, was subjected to fine bubble aeration. Airflow was provided by a fine bubble diffuser placed 5-cm above the bottom of the tank and fed by a blower with an electric power of $50 \mathrm{~W}$ (Figure 1). More details about the aeration device can be found in Andiloro et al., and Zema et al. [31,35,39]. 


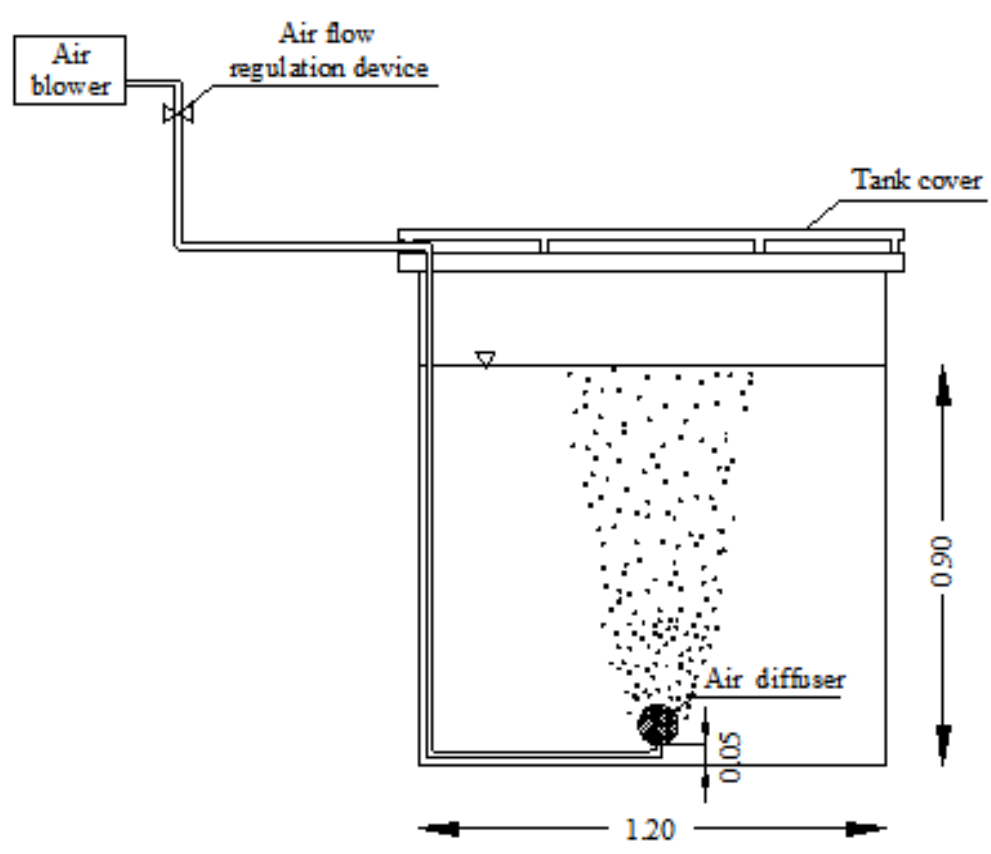

Figure 1. Section of the aerated tank that simulates lagooning for OMW depuration (measures are in metres).

Daily aeration flow rate was equal to $168 \mathrm{~L} / \mathrm{m}^{3}$ in each tank, except for the non-aerated tank (see Section 2.2.).

\subsection{Experimental Design}

Three series of depuration tests were carried out for 90 days. Each test was carried out in triplicate (three series of test, each one with three tanks, each tank in three replicates) (Table 1 ).

Table 1. Experimental design of the three-test series to simulate lagooning for OMW depuration.

\begin{tabular}{ccccc}
\hline Test Series & Tank & $\begin{array}{c}\text { Airflow Rate and } \\
\text { Aeration Time }\end{array}$ & PP Concentration & COD:N Ratio \\
\hline & A1 & Variable & Same & Same \\
A & A2 & Same & Variable & Same \\
& B1 & & & \\
B & B2 & S3 & Same & Variable \\
& C1 & Same & & \\
\hline
\end{tabular}

A first series (indicated as " $\mathrm{A}$ ") evaluated the effect of the aeration on the tank depuration performance. A first tank ("A1") was permanently aerated ( $24 \mathrm{~h}$ per day) with an airflow rate of $7 \mathrm{~L} / \mathrm{h} / \mathrm{m}^{3}$ (permanent aeration), while a second tank ("A2") was aerated using a flow rate of $14 \mathrm{~L} / \mathrm{h} / \mathrm{m}^{3}$ during the 12 night hours (intermittent aeration). The tanks "A1" and "A2" were aerated with the same daily flow rate $\left(168 \mathrm{~L} / \mathrm{m}^{3}\right)$. A third tank ("A3") was not aerated and assumed as control. PP concentration and COD:N ratio were set up as reported in Table 2. 
Table 2. Experimental conditions of the three test series to simulate lagooning for OMW depuration.

\begin{tabular}{|c|c|c|c|c|c|c|}
\hline \multirow{2}{*}{$\begin{array}{l}\text { Test } \\
\text { Series }\end{array}$} & \multirow{2}{*}{ Tank } & \multirow{2}{*}{ Condition } & \multicolumn{2}{|c|}{ Air Flow } & \multirow{2}{*}{$\begin{array}{c}\text { PP Concentration } \\
(\mathrm{g} / \mathrm{L})\end{array}$} & \multirow{2}{*}{ COD:N Ratio } \\
\hline & & & $\begin{array}{c}\text { Rate } \\
\left(\mathrm{L} / \mathrm{h}-\mathrm{m}^{3}\right)\end{array}$ & $\begin{array}{l}\text { Time } \\
\text { (Hours) }\end{array}$ & & \\
\hline \multirow{3}{*}{ A } & A1 & \multirow{3}{*}{$\begin{array}{c}\text { Aerated } \\
\text { Non- } \\
\text { aerated }\end{array}$} & 7 & 24 & $3.3 \pm 0.26$ & $103: 5 \pm 1.81$ \\
\hline & $\mathrm{A} 2$ & & 14 & 12 & $2.9 \pm 0.20$ & $101: 5 \pm 1.65$ \\
\hline & $\mathrm{A} 3$ & & 0 & 0 & $2.7 \pm 0.21$ & $105: 5 \pm 1.44$ \\
\hline \multirow{3}{*}{ B } & B1 & \multirow{3}{*}{ Aerated } & \multirow{3}{*}{7} & \multirow{3}{*}{24} & $3.3 \pm 0.25$ & $395: 5 \pm 8.69$ \\
\hline & B2 & & & & $6.6 \pm 0.62$ & $401: 5 \pm 8.67$ \\
\hline & B3 & & & & $13.2 \pm 1.29$ & $408: 5 \pm 8.99$ \\
\hline \multirow{3}{*}{$\mathrm{C}$} & $\mathrm{C} 1$ & \multirow{3}{*}{ Aerated } & \multirow{3}{*}{7} & \multirow{3}{*}{24} & $3.4 \pm 0.24$ & $100: 5 \pm 1.01$ \\
\hline & $\mathrm{C} 2$ & & & & $4.0 \pm 0.39$ & $200: 5 \pm 2.25$ \\
\hline & C3 & & & & $3.7 \pm 0.27$ & $400: 5 \pm 3.98$ \\
\hline
\end{tabular}

Notes: PP = polyphenols; $\mathrm{COD}=$ Chemical Oxygen Demand; $\mathrm{N}=$ Nitrogen; values are means \pm standard deviations.

The second series of tests (" $\mathrm{B}$ ") evaluated the effect of PP concentration on the tank depuration performance. The tests were carried out under three PP concentrations: 3.3 (tank "B1"), 6.6 ("B2") and 13.2 ("B3") g/L. Aeration was permanent (airflow rate of $7 \mathrm{~L} / \mathrm{h} / \mathrm{m}^{3}$ for $24 \mathrm{~h}$ ), as in the tank "A1"; COD:N was set up as reported in Table 2.

The third series (" $\mathrm{C}^{\prime \prime}$ ) analyzed the effect of three COD:N ratios on the tank performance. The tests were carried out under three COD:N ratios: 100:5 (tank "C1"), 200:5 ("C2") and 400:5 ("C3") (Table 2). The first ratio is ideal for aerobic treatments of wastewater [46]. Additionally, for this series, aeration was permanent; the PP concentration was set up as reported in Table 2.

No inoculum was used to start the experiment, since in lagoons the microbial mass naturally adapts to the wastewater characteristics, thanks to the long hydraulic retention time $[24,31]$.

\subsection{Initial Characteristics of OMW and Tank Preparation}

Raw OMW had an initial COD concentration of $280 \mathrm{~g} / \mathrm{L}$, a pH of 3.8, a COD:N ratio of 408:5, and PP concentration of $13.2 \mathrm{~g} / \mathrm{L}$ ( $\operatorname{tank}$ "B3"). The initial COD of the raw OMW was slightly over the typical range of continuous olive oil extraction process (20-200 g/L), as for Italian oil mills [47,48], but this parameter can be higher (up to 390-400 g/L for the oil extraction by pressure) [27,49]. These COD values are 20 to 4500 times higher than those of typical municipal wastewaters [10]. Moreover, both $\mathrm{pH}$ and PP concentrations are in the typical ranges of OMW (3 to 5.9 and 2 to $24 \mathrm{~g} / \mathrm{L}[10,50,51]$ ), although some authors have worked with OMW with very high PP concentrations (up to $80 \mathrm{~g} / \mathrm{L}$ ) [10].

OMW was prepared by dilution for the tanks of the series " $\mathrm{A}$ " and " $\mathrm{C}$ ", and the remaining tanks ("B1" and "B2") of series " $\mathrm{B}$ ", until the desired concentration of PP and COD: $\mathrm{N}$ ratio. In tanks " $\mathrm{A}$ ", urea was added, to increase $\mathrm{N}$ content until the constant and optimal ratio. In tanks " $\mathrm{C} 1$ " and "C2", both saccharose and urea were added to increase COD and COD:N ratio. About 70 and $140 \mathrm{~g} / \mathrm{L}$ of saccharose was added to the tanks "C2" and "C3", while 5.5 to $5.9 \mathrm{~g} / \mathrm{L}$ and 5.5 to $6.5 \mathrm{~g} / \mathrm{L}$ of urea $(46.6 \%$ of $\mathrm{N})$ was supplied to the tanks "A1" to "A3", and "C1" to "C3", respectively.

This experimental design allowed having OMW without disturbing factors (namely high COD:N ratio and PP concentration) in tanks " $\mathrm{A}$ ", with different PP concentration and the same COD: $\mathrm{N}$ in tanks " $\mathrm{B}$ ", and with the same PP concentration and different COD:N in tanks "C".

\subsection{Sample Analysis}

Samples were collected every week by taking $250 \mathrm{~mL}$ of the stored OMW and immediately transferring the sample to the laboratory. Here, the main chemical properties of the sampled OMW were evaluated using the following methods: digital multimeter probe 
HACH Lange HQ40 (pH); CHN analyser Leco series 628 (C:N ratio); cuvette cap tests, WTW, code 1.14555, photometer WTW, PhotoLab S12, on diluted, 1:10 v/v, samples (COD); Folin-Ciocalteu colorimetric method [52] and spectrophotometer PerkinElmer, Lambda 35 UV-VIS (PP concentration).

\subsection{Statistical Analysis}

A one-way ANalysis Of VAriance (ANOVA) was applied to each of the analyzed parameters (COD and PP concentrations, and $\mathrm{pH}$, considered as response variables), assuming the variable parameter (aeration condition in " $\mathrm{A}$ " series, $\mathrm{PP}$ concentration in "B" series, and COD:N ratio in "C series) (as factor). The statistical significance of the differences in the response variables was evaluated through pairwise comparisons using Tukey's test (at $p<0.05)$. To satisfy the equality of variance and normal distribution of sample distribution, the data were processed by normality tests or were square roottransformed whenever necessary. All statistical tests were carried out using XLSTAT rel. 2019.1 software (Addinsoft, Paris, France).

\section{Results and Discussion}

\subsection{Tanks " $A$ " (Effects of Aeration)}

In all tanks, COD monotonically decreased throughout the tests. The COD was significantly different only between the non-aerated ("A3") and the aerated tank "A1".

The COD removal rate was basically constant for the non-aerated tank ("A3"), where COD reduction was mainly attributed to the sedimentation of suspended solids rather than to micro-organism activity [27]. In contrast, in the aerated tests, this rate was higher in the initial and final periods (the latter increase was noticed especially for the tank "A2"). This means that the microbial mass was not initially able to exploit all the oxygen provided by the aeration (as shown by the lower decrease in COD observed at the test start in the tank with intermittent aeration), but the micro-organisms required an adaption phase of more than 50-60 days to the higher airflow rate (Figure 2a).

The low $\mathrm{pH}$ values of OMW (as for other vegetable wastewaters) are due to the presence of organic and phenolic acid [38]. In our experiment, the $\mathrm{pH}$ of wastewater decreased (from about 4.4-4.5 to 4.2-4.3) in the three tanks throughout the first 50 days, while an increase was subsequently noticed in all tests. Overall, a very slight variability between the initial and final $\mathrm{pH}$ was measured. The differences in $\mathrm{pH}$ were significant between the tanks "A2" on one side, and "A1" and "A3" on the other side (Figure 2b). While the $\mathrm{pH}$ decrease can be due to the formation of additional acids, the subsequent increase throughout the treatment could be explained by the degradation of organic compounds with $\mathrm{CO}-\mathrm{OH}$ and/or $\mathrm{OH}$ groups [38]. Very low and basically constant mean $\mathrm{pH}$ (4-4.3) was also reported by Gikas et al. [27] in lagoons under aerobic conditions, presumably due to the presence of fatty acids that have an inhibitory effect on micro-organism growth. In contrast, other studies showed a quick production of alkalinity due to the decomposition of organic compounds to $\mathrm{CO}_{2}$ through aerobic processes [28]. The latter authors suggest that $\mathrm{pH}$ should be in the range of 6.5 to 7.5 for the optimal growth of micro-organisms.

The differences in PP concentration were not significant among the three tanks. This concentration decreased by a lower rate throughout the first 20-30 days of the process. This decrease was faster in the following stage, but, while in the tank " $\mathrm{A} 3$ " the decreasing rate in the final phase was similar to the initial stage, in the aerated tank "A1" (with permanent aeration) this removal rate was still higher (Figure 2c). The increase in PP removal rate observed some days after the test start may be due to the progressive adaptation of the microbial mass to PP, reducing in part the toxicity effects. Adaptation of micro-organisms to environmental conditions is a key process in wastewater depuration. This may increase depuration rates in aerobic processes and energy yields in anaerobic reactors, by increasing the tolerance of micro-organisms to the inhibition effects played by phenolic compounds [17]. 

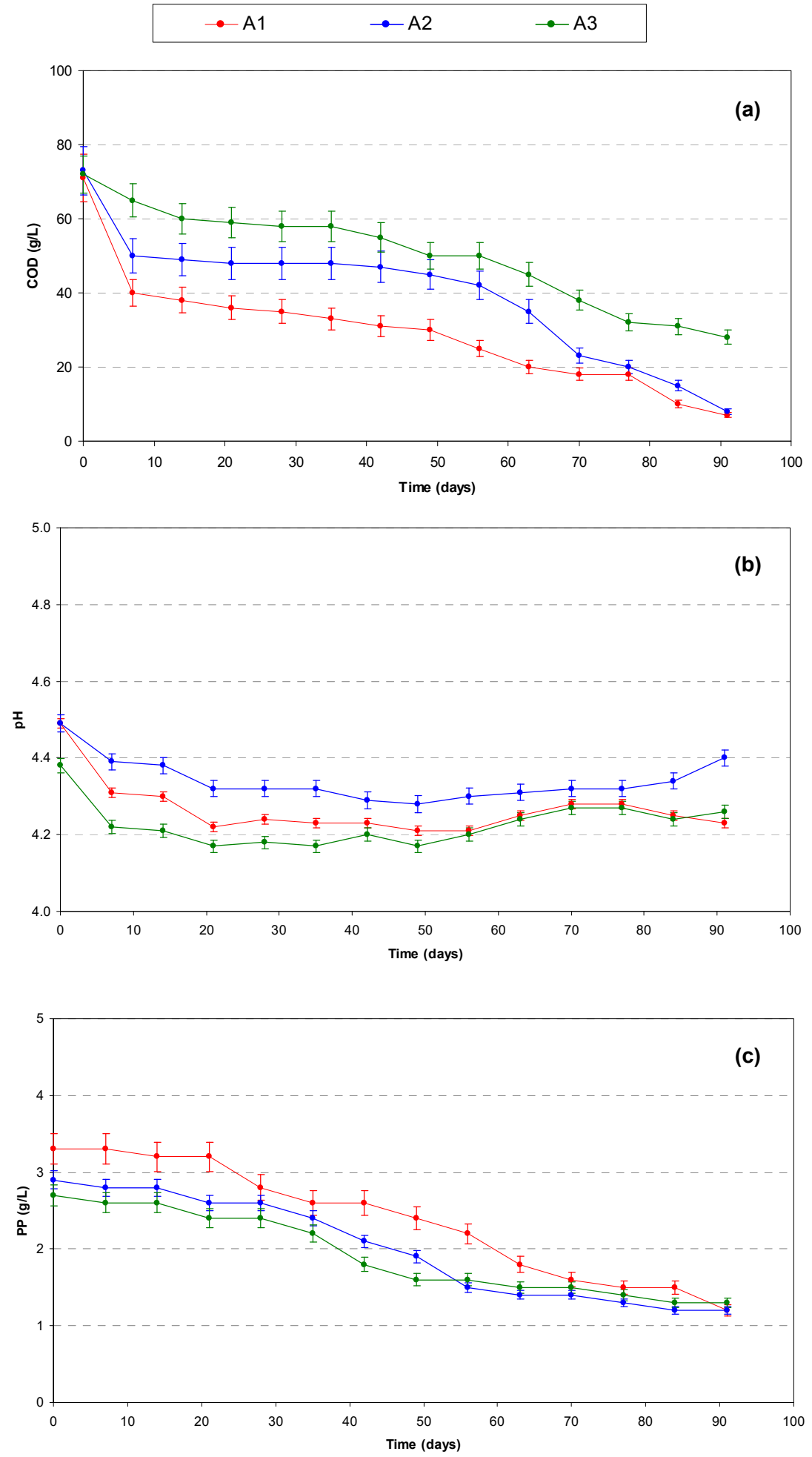

Figure 2. Temporal variability of $\operatorname{COD}(\mathbf{a}), \mathrm{pH}(\mathbf{b})$ and polyphenols $(\mathrm{PP}, \mathbf{c})$ in the " $\mathrm{A}$ " series of tests to simulate lagooning for OMW depuration.

The COD and PP removal rates were very similar between the aerated tanks (about $-90 \%$ ), but the tank "A1" (with permanent aeration) performed better in PP removal ( $-90 \%$ against $-67 \%$ of the tank " $\mathrm{A} 2$ "). The lowest depuration capacity was measured, as expected, for the non-aerated tank ("A3", $-61 \%$ for COD and $-52 \%$ for PP) (Figure $3 \mathrm{a}, \mathrm{c}$ ). As a matter of fact, in aerobic bioreactors, the addition of soluble oxygen provides microorganisms with optimum growth conditions together with large amounts of organic compounds [53]. 
Thanks to aeration, oxidizing microorganisms decompose the OM that is converted into simple forms of carbons without much pollution risks when the depurated effluents are returned to the environment. These micro-organisms use most of the remaining fraction of the pollutants to produce new cells [29].
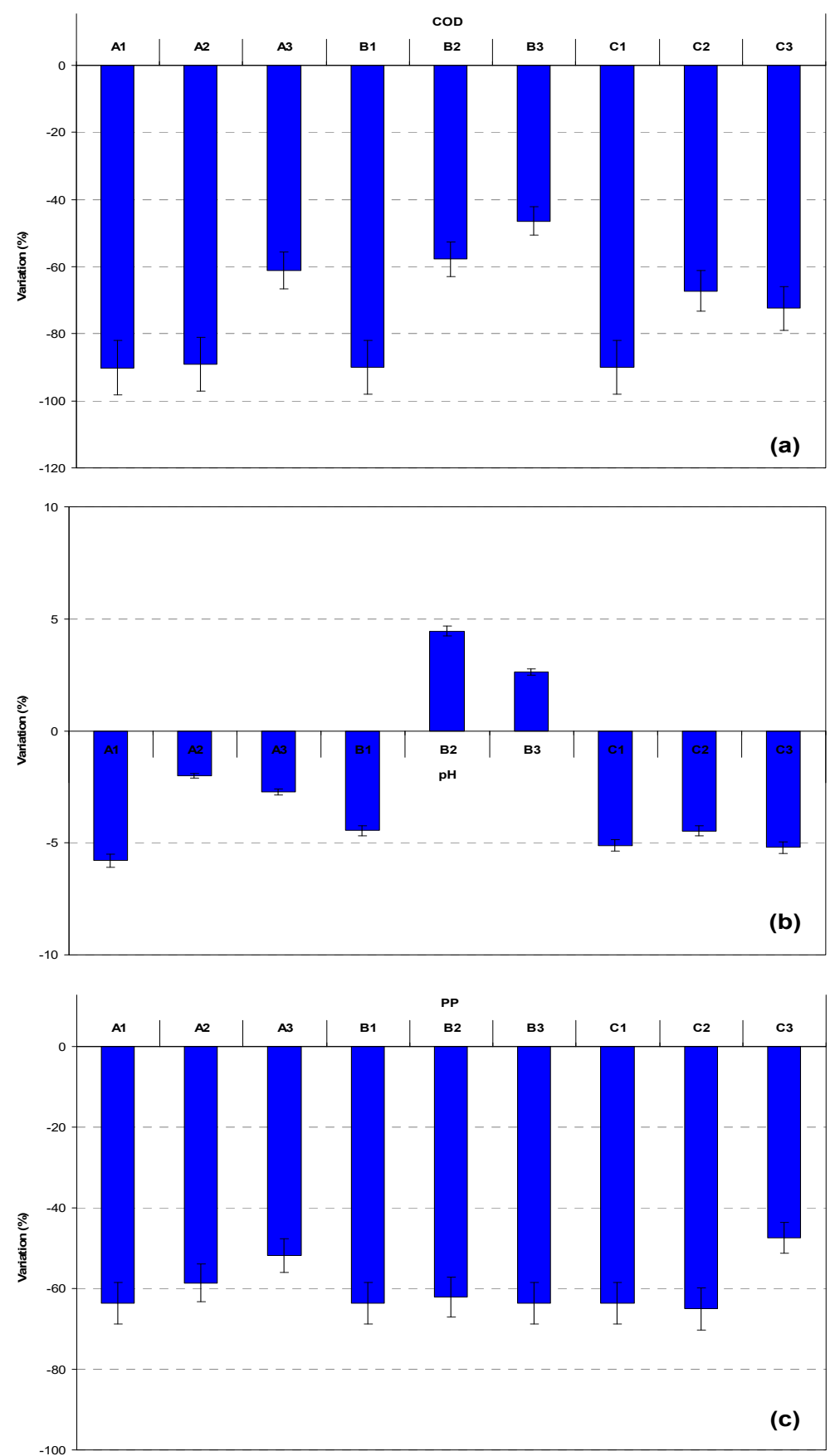

Figure 3. Percent variations of $\mathrm{COD}(\mathbf{a}), \mathrm{pH}(\mathbf{b})$ and polyphenols (PP, $\mathbf{c})$ between the start and the end of the three series of tests to simulate lagooning for OMW depuration.

The similarity of COD and PP degradation rates over time is in close accordance with Zenjari et al. [54], who demonstrated the existence of a positive correlation between the aerobic biodegradation of OM and phenolic compounds in OMW. In general, the aerobic treatment efficiency for high-strength wastewater in lagoons is around 60\% [25]. Other studies about OMW lagooning reported COD removal between 60 and 75\% [36], while, 
in activated sludge treatment, values up to $80-85 \%$ are typical (although the hydraulic retention time is much lower compared to lagooning, 20-25 days [32]).

Regarding the PP removal, while a mean reduction by only $13 \%$ was observed in the phenol concentration by Gikas et al. [27] in lagoons without aeration, Mantzavinos and Kalogerakis [36] reported rates from $65 \%$ even to $95 \%$ in aerobic treatments of OMW, while Benitez et al. [34] showed, under the same conditions, values that were always over $90 \%$.

An economic analysis should explore the incidence of the lower energy price in night hours (when the intermittent aeration is provided) on the overall performances of the aerated tanks. In other words, it should be evaluated whether it is economically convenient for a longer OMW storage in the tank with intermittent aeration to obtain the same COD and PP removal as in the tank with permanent aeration.

\subsection{Tanks " $B$ " (Effect of PP)}

The tank "B1" (with the lowest PP concentration) showed higher removal rates of both COD and PP in the first stage (20 days) of the depuration process, followed by slower decreases. For all the aerated tanks, the removal rates of both COD and PP were constant throughout the process (Figure $4 \mathrm{a}, \mathrm{c})$. The $\mathrm{pH}$ fluctuated for the tanks "B2" and "B3" (with lower initial content of PP) in the early stage, and slightly increased from the 40th day until the test end. In contrast, for the tank "B1" (with the lowest PP concentration), the $\mathrm{pH}$ initially decreased, then was stable, and finally increased (Figure $4 b$ ). The differences in the analyzed parameters were significant among all the tanks.

The tank "B1" showed the highest removal rate of COD $(-90 \%)$, which was noticeably lower in the tanks "B2" (-58\%) and "B3" (-46\%). The total removal of PP was instead very similar among the three tanks (about $-60 \%$ ) (Figure 3a,c). This means that, at the tested airflow rate and time, high PP concentrations are also not able to reduce the removal rates of $\mathrm{OM}$.

\subsection{Tanks "C" (Effect of COD:N Ratio)}

The variable COD:N ratio played a noticeable and significant influence on the depuration performances of the three tanks (Figure $5 \mathrm{a}, \mathrm{c}$ ). As a matter of fact, while the COD removal was the highest $(-90 \%)$ at the optimal COD:N (tank "C1"), higher values (therefore, under nitrogen shortage) reduced the process efficiency down to $67 \%$ (tank " $\mathrm{C} 2$ ") and $72 \%$ ("C3") (Figure 3a).

The analysis of the COD variability over time shows that the COD removal rates were quite similar among the three ratios in the first 40 days (Figure 5a). After a noticeable share of COD in the tanks "C1" (about 50\%) was removed (and thus the COD:N increased), the COD removal rate was much higher compared to the other tanks, where instead the COD removal rate was quite low throughout the whole test (Figure 5a). The lowest COD:N ratio noticeably influenced the PP removal rate, which was significantly lower in the tank "C3" ( $-47 \%$ against $64-65 \%$ in the tanks "C1" and "C2", Figure 3c). PP concentration showed a noticeable decrease throughout the first 40 days. Then, its reduction rate was lower for the tanks "C1" and "C2" (-0.6 g/L for both) and higher for the tank " $\mathrm{C} 2$ " $(-1.0 \mathrm{~g} / \mathrm{L})$ (Figure 5c). The values of $\mathrm{pH}$ decreased in the early stage of the process (7-10 days), and then became basically stable (Figure $5 b$ ), the differences being significant only between the tanks "C2" and "C3". Baashar et al. [46] found a COD removal by 75\% from pulp and paper mill wastewater at a COD:N:P ratio of about 170:5:1.5 under aerated conditions. 

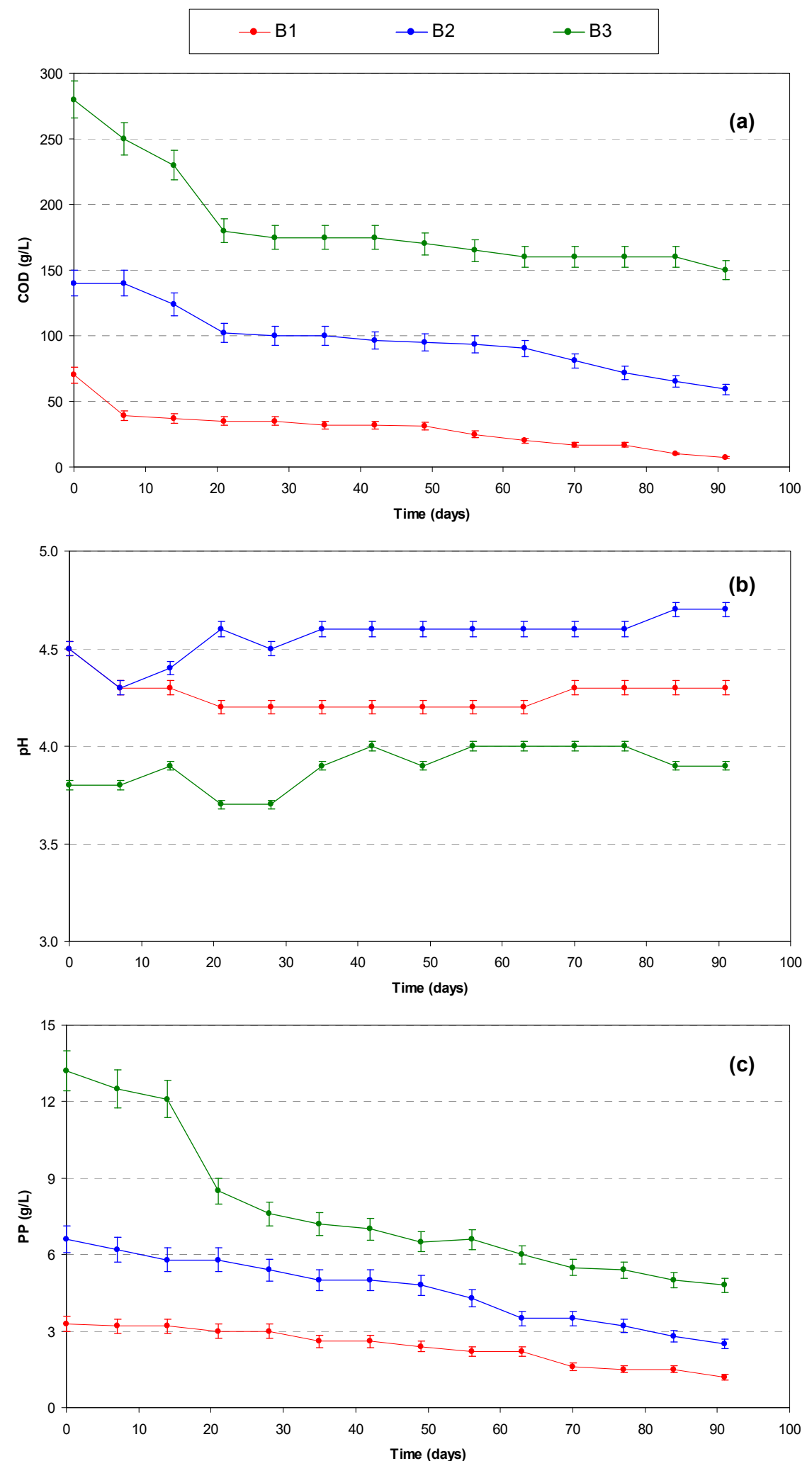

Figure 4. Temporal variability of $\mathrm{COD}(\mathbf{a}), \mathrm{pH}(\mathbf{b})$ and polyphenols $(\mathrm{PP}, \mathbf{c})$ in the " $\mathrm{B}$ " series of tests to simulate lagooning for OMW depuration. 

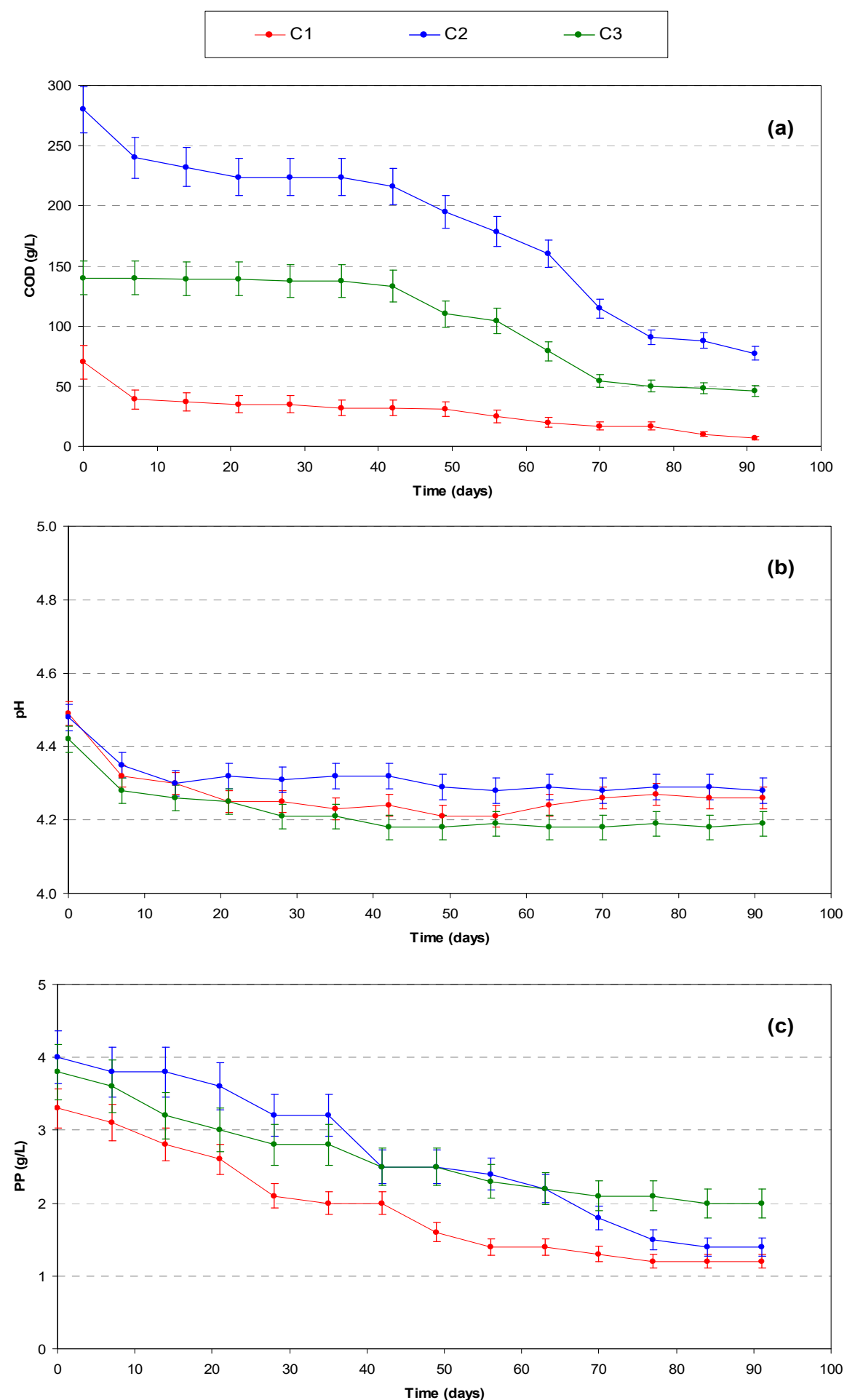

Figure 5. Temporal variability of $\mathrm{COD}(\mathbf{a}), \mathrm{pH}(\mathbf{b})$ and polyphenols $(\mathrm{PP}, \mathbf{c})$ in the " $\mathrm{C}$ " series of tests simulating lagooning for OMW depuration.

\section{Conclusions}

Compared to non-aerated tanks, aeration of OMW with moderate to high concentrations of COD and PP increased the removal rates from $61 \%$ to $90 \%$ (for COD) and from $52 \%$ to $64 \%$ (for PP). Permanent aeration is more advisable compared to intermittent flow rates, since, although being more expensive, it increases the depuration efficiency for both parameters. 
Increasing concentrations of PP noticeably reduced the COD removal rates, which were halved at a 4 -fold PP concentration. In contrast, the PP removal rate was constant at every concentration experimented.

Compared to the COD:N value suggested by literature for aerobic processes (100:5), a shortage in nitrogen availability reduced both COD (by about 20-25\%) and PP removal rates, the latter only when COD:N is higher than 400:5.

The $\mathrm{pH}$ was less influenced by variations in aeration rates, $\mathrm{PP}$ concentration and COD:N ratio compared to COD and PP removal.

More research is needed to: (i) understand the effects of the variability factors on the microbial composition and growth rate, considering their importance in the aeration processes; (ii) scale-up the lab-scale experimental plant to verify the lagoon performance by real-scale experiments.

Author Contributions: Conceptualization, G.B., D.A.Z. and S.M.Z.; methodology, G.B., P.D., A.F. and D.A.Z.; validation, G.B., D.A.Z. and S.M.Z.; formal analysis, G.B., P.D., A.F., D.A.Z. and S.M.Z.; data curation, S.A., G.B., P.D., A.F. and D.A.Z.; writing—original draft preparation, P.D. and D.A.Z.; writing-review and editing, G.B., P.D., D.A.Z. and S.M.Z.; supervision, G.B., D.A.Z. and S.M.Z.; project administration, S.M.Z.; funding acquisition, S.M.Z. All authors have read and agreed to the published version of the manuscript.

Funding: This research was funded by the National Project "PRIN—Programmi di Ricerca di Interesse Nazionale"-year 2015, by the Italian Ministry of Education, University and Research (M.I.U.R., Principal Investigator Attilio Toscano).

Data Availability Statement: The data presented in this study are available on request from the corresponding author.

Acknowledgments: We cordially thank the "Delia Coop." firm (Delianuova, Reggio Calabria, Italy) for hosting the experimental device and providing manpower for its management.

Conflicts of Interest: The authors declare no conflict of interest.

\section{References}

1. Zema, D.A.; Esteban Lucas-Borja, M.; Andiloro, S.; Tamburino, V.; Zimbone, S.M. Short-Term Effects of Olive Mill Wastewater Application on the Hydrological and Physico-Chemical Properties of a Loamy Soil. Agric. Water Manag. 2019, $221,312-321$. [CrossRef]

2. Bombino, G.; Andiloro, S.; Folino, A.; Lucas-Borja, M.E.; Zema, D.A. Short-Term Effects of Olive Oil Mill Wastewater Application on Soil Water Repellency. Agric. Water Manag. 2021, 244, 106563. [CrossRef]

3. Komnitsas, K.; Zaharaki, D. Pre-Treatment of Olive Mill Wastewaters at Laboratory and Mill Scale and Subsequent Use in Agriculture: Legislative Framework and Proposed Soil Quality Indicators. Resour. Conserv. Recycl. 2012, 69, 82-89. [CrossRef]

4. Moreno, L.; González, A.; Cuadros-Salcedo, F.; Cuadros-Blázquez, F. Feasibility of a Novel Use for Agroindustrial Biogas. J. Clean. Prod. 2017, 144, 48-56. [CrossRef]

5. Di Serio, M.G.; Lanza, B.; Mucciarella, M.R.; Russi, F.; Iannucci, E.; Marfisi, P.; Madeo, A. Effects of Olive Mill Wastewater Spreading on the Physico-Chemical and Microbiological Characteristics of Soil. Int. Biodeterior. Biodegrad. 2008, 62, $403-407$. [CrossRef]

6. Amaral, C.; Lucas, M.S.; Coutinho, J.; Crespí, A.L.; do Rosário Anjos, M.; Pais, C. Microbiological and Physicochemical Characterization of Olive Mill Wastewaters from a Continuous Olive Mill in Northeastern Portugal. Bioresour. Technol. 2008, 99, 7215-7223. [CrossRef] [PubMed]

7. Tziotzios, G.; Michailakis, S.; Vayenas, D.V. Aerobic Biological Treatment of Olive Mill Wastewater by Olive Pulp Bacteria. Int. Biodeterior. Biodegrad. 2007, 60, 209-214. [CrossRef]

8. Karaouzas, I.; Skoulikidis, N.T.; Giannakou, U.; Albanis, T.A. Spatial and Temporal Effects of Olive Mill Wastewaters to Stream Macroinvertebrates and Aquatic Ecosystems Status. Water Res. 2011, 45, 6334-6346. [CrossRef]

9. Dermeche, S.; Nadour, M.; Larroche, C.; Moulti-Mati, F.; Michaud, P. Olive Mill Wastes: Biochemical Characterizations and Valorization Strategies. Process. Biochem. 2013, 48, 1532-1552. [CrossRef]

10. Azbar, N.; Bayram, A.; Filibeli, A.; Muezzinoglu, A.; Sengul, F.; Ozer, A. A Review of Waste Management Options in Olive Oil Production. Crit. Rev. Environ. Sci. Technol. 2004, 34, 209-247. [CrossRef]

11. Aggoun, M.; Arhab, R.; Cornu, A.; Portelli, J.; Barkat, M.; Graulet, B. Olive Mill Wastewater Microconstituents Composition According to Olive Variety and Extraction Process. Food Chem. 2016, 209, 72-80. [CrossRef]

12. McNamara, C.J.; Anastasiou, C.C.; O'Flaherty, V.; Mitchell, R. Bioremediation of Olive Mill Wastewater. Int. Biodeterior. Biodegrad. 2008, 61, 127-134. [CrossRef] 
13. Jarboui, R.; Hadrich, B.; Gharsallah, N.; Ammar, E. Olive Mill Wastewater Disposal in Evaporation Ponds in Sfax (Tunisia): Moisture Content Effect on Microbiological and Physical Chemical Parameters. Biodegradation 2009, 20, 845-858. [CrossRef] [PubMed]

14. Gómez, A.; Zubizarreta, J.; Rodrigues, M.; Dopazo, C.; Fueyo, N. An Estimation of the Energy Potential of Agro-Industrial Residues in Spain. Resour. Conserv. Recycl. 2010, 54, 972-984. [CrossRef]

15. Dourou, M.; Kancelista, A.; Juszczyk, P.; Sarris, D.; Bellou, S.; Triantaphyllidou, I.E.; Rywinska, A.; Papanikolaou, S.; Aggelis, G. Bioconversion of Olive Mill Wastewater into High-Added Value Products. J. Clean. Prod. 2016, 139, 957-969. [CrossRef]

16. Orive, M.; Cebrián, M.; Zufía, J. Techno-Economic Anaerobic Co-Digestion Feasibility Study for Two-Phase Olive Oil Mill Pomace and Pig Slurry. Renew. Energy 2016, 97, 532-540. [CrossRef]

17. Calabrò, P.S.; Fòlino, A.; Tamburino, V.; Zappia, G.; Zema, D.A. Increasing the Tolerance to Polyphenols of the Anaerobic Digestion of Olive Wastewater through Microbial Adaptation. Biosyst. Eng. 2018, 172, 19-28. [CrossRef]

18. Zema, D.A. Planning the Optimal Site, Size, and Feed of Biogas Plants in Agricultural Districts. Biofuels Bioprod. Bioref. 2017, 11, 454-471. [CrossRef]

19. Barbera, A.C.; Maucieri, C.; Ioppolo, A.; Milani, M.; Cavallaro, V. Effects of Olive Mill Wastewater Physico-Chemical Treatments on Polyphenol Abatement and Italian Ryegrass (Lolium Multiflorum Lam.) Germinability. Water Res. 2014, 52, 275-281. [CrossRef] [PubMed]

20. Mekki, A.; Dhouib, A.; Sayadi, S. Changes in Microbial and Soil Properties Following Amendment with Treated and Untreated Olive Mill Wastewater. Microbiol. Res. 2006, 161, 93-101. [CrossRef]

21. Chartzoulakis, K.; Psarras, G.; Moutsopoulou, M.; Stefanoudaki, E. Application of Olive Mill Wastewater to a Cretan Olive Orchard: Effects on Soil Properties, Plant Performance and the Environment. Agric. Ecosyst. Environ. 2010, 138, 293-298. [CrossRef]

22. Juanicó, M.; Milstein, A. Semi-Intensive Treatment Plants for Wastewater Reuse in Irrigation. Water Sci. Technol. 2004, 50, 55-60. [CrossRef]

23. Salgot, M.; Huertas, E.; Weber, S.; Dott, W.; Hollender, J. Wastewater Reuse and Risk: Definition of Key Objectives. Desalination 2006, 187, 29-40. [CrossRef]

24. Zema, D.A.; Calabro, P.S.; Folino, A.; Tamburino, V.; Zappia, G.; Zimbone, S.M. Wastewater Management in Citrus Processing Industries: An Overview of Advantages and Limits. Water (Switz.) 2019, 11, 2481. [CrossRef]

25. Hamza, R.A.; Iorhemen, O.T.; Tay, J.H. Anaerobic-Aerobic Granular System for High-Strength Wastewater Treatment in Lagoons. Adv. Environ. Res. 2016, 5, 169-178. [CrossRef]

26. Isosaari, P.; Hermanowicz, S.W.; Rubin, Y. Sustainable Natural Systems for Treatment and Disposal of Food Processing Wastewater. Crit. Rev. Environ. Sci. Technol. 2010, 40, 662-697. [CrossRef]

27. Gikas, G.D.; Tsakmakis, I.D.; Tsihrintzis, V.A. Hybrid Natural Systems for Treatment of Olive Mill Wastewater. J. Chem. Technol. Biotechnol. 2018, 93, 800-809. [CrossRef]

28. Pishgar, R.; Hamza, R.A.; Tay, J.H. Augmenting Lagoon Process Using Reactivated Freeze-Dried Biogranules. Appl. Biochem. Biotechnol. 2017, 183, 137-154. [CrossRef]

29. Rozzi, A.; Malpei, F. Treatment and Disposal of Olive Mill Effluents. Int. Biodeterior. Biodegrad. 1996, 38, 135-144. [CrossRef]

30. Rajbhandari, B.K.; Annachhatre, A.P. Anaerobic Ponds Treatment of Starch Wastewater: Case Study in Thailand. Bioresour. Technol. 2004, 95, 135-143. [CrossRef]

31. Andiloro, S.; Bombino, G.; Tamburino, V.; Zema, D.A.; Zimbone, S.M. Aerated Lagooning of Agro-Industrial Wastewater: Depuration Performance and Energy Requirements. J. Agric. Eng. 2013, 7, 44. [CrossRef]

32. Paraskeva, P.; Diamadopoulos, E. Technologies for Olive Mill Wastewater (OMW) Treatment: A Review. J. Chem. Technol. Biotechnol. 2006, 81, 1475-1485. [CrossRef]

33. S'habou, R.; Zairi, M.; Kallel, A.; Aydi, A.; Ben Dhia, H. Assesing the Effect of an Olive Mill Wastewater Evaporation Pond in Sousse, Tunisia. Environ. Geol. 2009, 58, 679. [CrossRef]

34. Benitez, F.J.; Beltran-Heredia, J.; Torregrosa, J.; Acero, J.L. Treatment of Olive Mill Wastewaters by Ozonation, Aerobic Degradation and the Combination of Both Treatments. J. Chem. Technol. Biotechnol. 1999, 74, 639-646. [CrossRef]

35. Zema, D.A.; Andiloro, S.; Bombino, G.; Caridi, A.; Sidari, R.; Tamburino, V. Comparing Different Schemes of Agricultural Wastewater Lagooning: Depuration Performance and Microbiological Characteristics. Water Air Soil Pollut. 2016, 227. [CrossRef]

36. Mantzavinos, D.; Kalogerakis, N. Treatment of Olive Mill Effluents. Environ. Int. 2005, 31, 289-295. [CrossRef]

37. Jail, A.; Boukhoubza, F.; Nejmeddine, A.; Sayadi, S.; Hassani, L. Co-Treatment of Olive-Mill and Urban Wastewaters by Experimental Stabilization Ponds. J. Hazard. Mater. 2010, 176, 893-900. [CrossRef] [PubMed]

38. Jail, A.; Boukhoubza, F.; Nejmeddine, A.; Duarte, J.C.; Sayadi, S.; Hassani, L. Traitement des effluents d'huileries par un procédé combinant un traitement intensif (Jet-Loop Reactor) suivi d'un traitement extensif (bassins de stabilisation): Treatment of olive mill wastewater by a process combining an intensive treatment (Jet-Loop Reactor) followed by an extensive treatment (stabilization ponds). Environ. Technol. 2010, 31, 533-543. [CrossRef]

39. Zema, D.A.; Andiloro, S.; Bombino, G.; Tamburino, V.; Sidari, R.; Caridi, A. Depuration in Aerated Ponds of Citrus Processing Wastewater with a High Concentration of Essential Oils. Environ. Technol. 2012, 33. [CrossRef] [PubMed] 
40. Zema, D.A.; Zappia, G.; Benalia, S.; Zimbalatti, G.; Perri, E.; Urso, E.; Tamburino, V.; Bernardi, B. Limiting Factors to Anaerobic Digestion of Olive Mill Wastewater Blends under Mesophilic and Thermophilic Conditions. J. Agric. Eng. 2018, 49, 130-137. [CrossRef]

41. Borja, R.; Banks, C.J.; Maestro-Durán, R.; Alba, J. The Effects of the Most Important Phenolic Constituents of Olive Mill Wastewater on Batch Anaerobic Methanogenesis. Environ. Technol. 1996, 17, 167-174. [CrossRef]

42. Khoufi, S.; Aloui, F.; Sayadi, S. Treatment of Olive Oil Mill Wastewater by Combined Process Electro-Fenton Reaction and Anaerobic Digestion. Water Res. 2006, 40, 2007-2016. [CrossRef]

43. Elimination of Polyphenols Toxicity from Olive Mill Wastewater Sludge by Its Co-Composting with Sesame Bark-ScienceDirect. Available online: https://www.sciencedirect.com/science/article/pii/S0304389408006134 (accessed on 8 June 2021).

44. Zema, D.A.; Calabrò, P.S.; Folino, A.; Tamburino, V.; Zappia, G.; Zimbone, S.M. Valorisation of Citrus Processing Waste: A Review. Waste Manag. 2018, 80, 252-273. [CrossRef] [PubMed]

45. Mielczarek, A.T.; Kragelund, C.; Eriksen, P.S.; Nielsen, P.H. Population Dynamics of Filamentous Bacteria in Danish Wastewater Treatment Plants with Nutrient Removal. Water Res. 2012, 46, 3781-3795. [CrossRef]

46. Bashaar, Y.A. Nutrients Requirements in Biological Industrial Wastewater Treatment. Afr. J. Biotechnol. 2004, 3, 236-238. [CrossRef]

47. Elkacmi, R.; Bennajah, M. Advanced Oxidation Technologies for the Treatment and Detoxification of Olive Mill Wastewater: A General Review. J. Water Reuse Desalination 2019, 9, 463-505. [CrossRef]

48. Frascari, D.; Rubertelli, G.; Arous, F.; Ragini, A.; Bresciani, L.; Arzu, A.; Pinelli, D. Valorisation of Olive Mill Wastewater by Phenolic Compounds Adsorption: Development and Application of a Procedure for Adsorbent Selection. Chem. Eng. J. 2019, 360, 124-138. [CrossRef]

49. Ben Sassi, A.; Boularbah, A.; Jaouad, A.; Walker, G.; Boussaid, A. A Comparison of Olive Oil Mill Wastewaters (OMW) from Three Different Processes in Morocco. Process. Biochem. 2006, 41, 74-78. [CrossRef]

50. Rahmanian, N.; Jafari, S.M.; Galanakis, C.M. Recovery and Removal of Phenolic Compounds from Olive Mill Wastewater. J. Am. Oil Chem. Soc. 2014, 91, 1-18. [CrossRef]

51. Borja, R.; Martín, A.; Alonso, V.; García, I.; Banks, C.J. Influence of Different Aerobic Pretreatments on the Kinetics of Anaerobic Digestion of Olive Mill Wastewater. Water Res. 1995, 29, 489-495. [CrossRef]

52. Folin, O.; Ciocalteu, V. On tyrosine and tryptophane determinations in Proteins. J. Biol. Chem. 1927, 73, 627-650. [CrossRef]

53. Bawab, A.A.; Ghannam, N.; Abu-Mallouh, S.; Bozeya, A.; Abu-Zurayk, R.A.; Al-Ajlouni, Y.A.; Alshawawreh, F.; Odeh, F.; Abu-Dalo, M.A. Olive mill wastewater treatment in Jordan: A review. IOP Conf. Ser. Mater. Sci. Eng. 2018, 305, 012002. [CrossRef]

54. Zenjari, B.; Hafidi, M.; Hadrami, I.; Bailly, J.R.; Nejmeddine, A. Traitment Aerobie Des Effluents d'huilerie Par Les MicroOrganismes Du Sol. Agrochim. PISA 1999, 43, 277-286. 